OPEN ACCESS

Edited by:

Manja Zec.

University of Arizona, United States

Reviewed by:

Wimal Pathmasiri,

University of North Carolina at Chapel Hill, United States

Robert Fred Clark,

RTI International, United States

*Correspondence:

Marija Knez

marijaknez186@gmail.com

Specialty section:

This article was submitted to Nutrigenomics,

a section of the journal

Frontiers in Nutrition

Received: 26 March 2021

Accepted: 25 June 2021

Published: 30 July 2021

Citation:

Knez M and Glibetic M (2021) Zinc as a Biomarker of Cardiovascular Health.

Front. Nutr. 8:686078.

doi: 10.3389/fnut.2021.686078

\section{Zinc as a Biomarker of Cardiovascular Health}

\author{
Marija Knez* and Maria Glibetic \\ Centre of Research Excellence in Nutrition and Metabolism, National Institute for Medical Research, University of Belgrade, \\ Belgrade, Serbia
}

The importance of zinc ( $Z n)$ for cardiovascular health continuously gains recognition. As shown earlier, compromised $\mathrm{Zn}$ homeostasis and prolonged inflammation are common features in various cardiovascular diseases (CVDs). Similarly, Zn biochemistry alters several vascular processes, and $\mathrm{Zn}$ status is an important feature of cardiovascular health. Zn deficiency contributes to the development of CVDs; thus, Zn manipulations, including Zn supplementation, are beneficial for preventing and treating numerous cardiovascular (CV) disorders. Finally, additional long-term, well-designed studies, performed in various population groups, should be pursued to further clarify significant relationships between $\mathrm{Zn}$ and CVDs.

Keywords: zinc, cardiovascular diseases, zinc deficiency, zinc supplementation, obesity, hypertension, cardiovascular health

\section{INTRODUCTION}

Zinc $(\mathrm{Zn})$ is one of the most essential micronutrients involved in numerous crucial biological functions, i.e., cell differentiation and proliferation, cellular transport, DNA synthesis, endocrine, immune, and central nervous system functioning, reproduction, gene expression, and homeostasis (1). With the capacity to bind more than 300 enzymes and over 2,000 transcriptional factors, it is often regarded as a multipurpose trace element (2). $\mathrm{Zn}$ is a major antioxidant mineral responsible for inhibiting expansion and negative effects of free radicals and regulating the oxidant-antioxidant balance of cells (3). Zn deficiency significantly affects the functioning of biological systems, creates dysfunctions in humoral and cell-mediated immunity, consequently, increases the vulnerability to infections-predisposing people to disturbances in gut microbiota activity, increases the incidence of bacterial, viral, and fungal infections, and leads to the progression of chronic and degenerative diseases, i.e., type 2 diabetes mellitus (T2DM), cardiovascular diseases (CVDs), and cancers (3). CVDs are the leading cause of morbidity and mortality worldwide, and 17.9 million people died from CVDs in 2016, representing 31\% of global deaths (4). CVD-related deaths are projected to reach 23.6 million annually by 2030 (1). Three-quarters of these deaths occur in low-income and middle-income countries (4). The deficiency of $\mathrm{Zn}$ affects $17 \%$ of the global population, up to $35 \%$ in low-income populations, i.e., South Asia and Africa (1). An association between Zn intake and $\mathrm{Zn}$ status with the pathogenesis of CVDs is demonstrated by several experimental and clinical studies $(5,6)$. Imbalances in $\mathrm{Zn}$ homeostasis contribute significantly to the development of CVDs, such as coronary heart disease (CHD), congestive heart failure (HF), ischemic cardiomyopathy (CM), myocardial infarction (MI), sudden cardiac death (SCD), and CVD mortality, in general (5). Antioxidant and prooxidant functions of $\mathrm{Zn}$ may have various positive effects on $\mathrm{CV}$ health and could prevent the development of CVDs (6). 
This study provides a concise and thorough overview of the relationship between $\mathrm{Zn}$ homeostasis and CVDs. The importance and potential suitability of $\mathrm{Zn}$ status as a biomarker of $\mathrm{CV}$ health are discussed, highlighting present controversies and research gaps that entail further research studies.

\section{ZINC DEFICIENCY-A CONTRIBUTING FACTOR FOR DEVELOPING CVDS}

Zinc is a major component of numerous enzymes within the human body. It controls the functioning of metalloenzymes, transcription factors, angiotensin-converting enzymes, desaturases, superoxide dismutases, and many others (1). Consequently, deficiency of $\mathrm{Zn}$ leads to apoptosis, inflammation, and oxidative stress, all well-acknowledged risk factors for the development of CVDs (7). Perturbations in $\mathrm{Zn}$ homeostasis affect the vascular endothelium (8). Zn deficiency weakens vascular health, impairs appropriate fatty acid and carbohydrate metabolism, and negatively impacts the cell structure of the aorta (9). Impaired $\mathrm{Zn}$ homeostasis is associated with common genomic and proteomic modifications that relate to CVDs (10). Zn controls the arteriosclerotic process, and inadequate $\mathrm{Zn}$ intake leads to increased oxidative stress, disrupted nitric oxide (NO), and nuclear factor kappa-light-chain-enhancer of activated B-cell (NF-kB) signaling and contributes considerably to endothelial damage and development of arteriosclerosis (ARS) (6). The rate of ARS, ischemic injuries, ischemic CM, and ischemic HF amplifies in line with decreasing plasma $\mathrm{Zn}$ levels $(11,12)$. Likewise, dietary $\mathrm{Zn}$ intake and $\mathrm{Zn}$ deficiency are adversely linked to subclinical ARS as demonstrated through carotid intima-media thickness $(13,14)$. Heart development is sensitive to $\mathrm{Zn}$ deficiency, and maternal $\mathrm{Zn}$ deficiency is linked to a high incidence of fetal heart abnormalities (15). Furthermore, $\mathrm{Zn}$ inadequacy prevents adequate development of cardiac tissues and increases blood pressure in fetuses and infants (16). Excessive embryonic cell death occurs after episodes of Zn deficiency (15). Proatherogenic factors, released during $\mathrm{Zn}$ deficiency, increase the incidence of arrhythmias, strokes, CM, and many other CV system pathologies $(5,17)$. There is an inverse relation between the serum $\mathrm{Zn}$ concentrations and the risk of CVDs in high-risk populations (18). Besides, lower serum Zn levels are associated with a higher risk of CVDs, with the greatest relations reported in most vulnerable populations, i.e., patients with diabetes and coronary angiography (18). Stimulated expression of inflammatory cytokines, i.e., interleukin 6 (IL-6), interleukin 2 (IL-2), interleukin 1 beta (IL-1 $\beta$ ), tumor necrosis factor alpha (TNF- $\alpha$ ), and increased oxidative stress are aggravated under Zn deficiency conditions (19). Similarly, cytokines can upregulate or downregulate the expression of particular cellular $\mathrm{Zn}$ transporters (20). Twenty-four $\mathrm{Zn}$ transporters are found within the human heart muscle tissue, so disturbances in $\mathrm{Zn}$ homeostasis may lead to CVDs (21). Turbulences in $\mathrm{Zn}$ homeostasis contribute to the development of hypertension (HT) (22). Through the renin-angiotensin-aldosterone system, $\mathrm{Zn}$ regulates arterial pressure and plays an important role in the etiopathogenesis of arterial HT (23).
Adequate $\mathrm{Zn}$ levels are a critical component in peroxisome proliferator-activated receptor signaling during atherosclerosis (ATS) (23). Furthermore, patients with coronary heart disease have poor $\mathrm{Zn}$ status (17). Zn deficiency contributes to the thickening of the vascular wall due to enhanced proliferation and hypertrophy (24). Low serum Zn levels are measured in people with $\operatorname{HF}(25,26)$. $\mathrm{Zn}$ also has a role in redox signaling pathways, and it improves antiapoptotic, anti-inflammatory, and antioxidant activities (27). Deficiency of $\mathrm{Zn}$ can degenerate essential proteins like protein creatine kinase (C kinase), stimulate the production of inflammatory cytokines and Creactive proteins, and may trap constituents in monocytes and macrophages (19). Serum Zn levels are considerably diminished in patients with left ventricular hypertrophy (LVH), and a significant inverse relation is seen between $\mathrm{Zn}$ status and LVH (5). Patients with ischemic stroke have lower serum $\mathrm{Zn}$ levels than healthy subjects (13). Similarly, lower serum Zn levels are seen in patients with $\mathrm{HF}$ and patients with left ventricular diastolic function (28). Besides, serum $\mathrm{Zn}$ levels are inversely associated with diminished glucose homeostasis and insulin resistance (29). Low serum $\mathrm{Zn}$ concentration predicts mortality in patients that need coronary angiography (30). What is more, serum $\mathrm{Zn}$ levels could be a valid diagnostic indicator for acute MI (31). According to the meta-analysis data, an increased prevalence of coronary artery disease (CAD) is linked to a lower dietary $\mathrm{Zn}$ intake, with a direct association between $\mathrm{Zn}$ status and MI (31).

\section{ZINC INTERVENTIONS ALLEVIATE RISK FACTORS FOR CVDS}

Cohort studies, randomized trials, and meta-analyses of these studies propose that higher consumption of dietary $\mathrm{Zn}$ is linked to reduced risk of CVDs. Administration of $\mathrm{Zn}$ stimulates myocardial healing and improves arrhythmias (32). Besides, $\mathrm{Zn}$ is a wound-healing agent that supports cardiac steam cell survival, a critical element of cardiac healing (12). Zn supplementation has an atheroprotective effect (20) and contributes to a higher concentration of high-density lipoprotein cholesterol (HDL-C) and apoproteins, and lower total cholesterol (TC) levels (33). Higher serum $\mathrm{Zn}$ concentrations are associated with a decline in relative risk of death of CVDs (12). Reduced prevalence of CAD and T2DM is correlated with higher dietary Zn intakes (34, 35). Additionally, higher plasma $\mathrm{Zn}$ concentration is associated with a diminished risk of mortality of vascular disease (VD) $(30,36)$. Zn supplementation could potentially increase the effectiveness of currently used therapeutic drugs for managing CVDs (37). Finally, recently presented data of a systematic review and meta-analysis point out that low-dose and long-duration $\mathrm{Zn}$ interventions are of identical or in some instances of even larger magnitude and with even more beneficial effects compared to high-dose and short-duration interventions. Long-duration Zn studies, for 12 weeks or longer, alleviated risk factors for T2DM and CVDs, such as blood glucose, total fats, triglycerides (TGs), and low-density lipoprotein cholesterol (LDL-C), while the longer duration of low $\mathrm{Zn}$ doses affected a larger number of risk factors (38). 


\section{LIMITED KNOWLEDGE ON VASCULAR ROLES OF ZINC TRANSPORTER PROTEINS}

Twenty-four Zip transporters are present within human heart muscle tissues, so disturbances in $\mathrm{Zn}$ homeostasis are strongly related to CVDs (21). Zrt, Irt-like protein2 (Zip2), Zip12, Zip14, and $\mathrm{Zn}$ transporter1 (ZnT1) and ZnT2 are linked to the vascular biology of CVDs (37).

For example, Zip2 has a beneficial role in the postconditioning cardioprotective process (32). Zip2 polymorphism is associated with human carotid artery disease in the elderly (39). In addition, Zip12 is involved in the uptake of $\mathrm{Zn}$ into the vascular wall (22). Yet, limited information is available on vascular roles of Zip14, ZnT1, and ZnT4 (37).

Furthermore, $\mathrm{ZnT} 1$ is involved in cardiac electrophysiological effects of $\mathrm{Zn}$ and increased $\mathrm{ZnT1}$ expression is seen in patients with atrial fibrillation $(40,41)$. $\mathrm{Zn}$ has a central role in the generation of $\mathrm{NO}$ and actions that have multiple implications for vascular endothelial and smooth muscle functions, i.e., vascular smooth muscle relaxation, antiplatelet properties, and protection of vascular endothelium against oxidative damage (42). The availability and function of NO are disturbed in $\mathrm{Zn}$ deficiency (37). The action of NO is controlled by both $\mathrm{Zn}$ and metallothionein (MT), so an insufficient supply of endothelial $\mathrm{Zn}$ will make $\mathrm{NO}$ ineffective as a CVD therapeutic agent (37).

Investigation of the genetic polymorphism of $\mathrm{Zn}$ transporters gains more and more attention. The polymorphism of $\mathrm{Zn}$ transporters confers a predisposition to various chronic and agerelated diseases, such as chronic CVDs $(43,44)$. A common polymorphism in the ZnT8 gene, on the $\mathrm{C}$ allele, is associated with a higher risk of developing T2DM and metabolic syndrome $(45,46)$. Several single-nucleotide polymorphisms modulate $\mathrm{Zn}$ intake and status (47). There is an interaction between certain dietary components (i.e., omega three fatty acid intake) with $\mathrm{Zn}$ transporters in relation to the risk factors for CVD development (48). MT polymorphisms, MT1A, MT1B, MT2, and MT4, are often associated with dietetic neuropathy, blood pressure, inflammatory cytokine levels, DM, and CVDs (4951). Similarly, there is an indirect involvement of uncoupling proteins in the MT-dependent reduction in the free radicalinduced cardiac toxicity (52). Finally, ZnT1, ZnT4, ZnT5, ZnT6, ZnT7, and ZnT9 polymorphisms are linked to T2DM, dyslipidemia, and insulin resistance, all well-known CVD risk factors $(53,54)$.

\section{ZINC AND INDEPENDENT RISK FACTORS OF CVDs}

Several risk factors (i.e., T2DM, obesity, and HT) that predispose to $\mathrm{VD}$ are linked to irregularities in $\mathrm{Zn}$ homeostasis in individual organs or the whole body (55). A direct association between serum $\mathrm{Zn}$ and metabolic risk factors for the development of CVD, i.e., serum lipids,
T2DM, and obesity, is shown $(35,55,56)$. Zn plays an important role in insulin synthesis, crystallization, storage, and secretion in the pancreatic $\beta$-cells (57). Oxidative stress, a key risk factor in the pathogenesis of diabetes mellitus $(\mathrm{DM})$, is aggravated under $\mathrm{Zn}$ deficiency states (58). $\mathrm{Zn}$ has insulin-mimicking properties, stimulates glucose uptake in insulin-dependent tissues, and regulates gluconeogenic enzymes (59).

ZnT8, located on dense core vesicles in $\beta$-cells, has a central role in the transportation of $\mathrm{Zn}$ into insulin secretory granules of $\beta$-cells and is identified as a novel therapeutic target in patients with diabetes $(18,60)$. Diabetes is often accompanied by hypozincemia and hyperzincuria (33, 61). Furthermore, $\mathrm{Zn}$ stimulates insulin binding to hepatocyte membranes and low $\mathrm{Zn}$ status considerably decreases the reaction of tissues to insulin (62). There is an inverse correlation between femur $\mathrm{Zn}$ and serum glucose concentrations (63).

Interestingly, a moderately high $\mathrm{Zn}$ intake could reduce the risk of diabetes by $13 \%$, up to $40 \%$ in people living in rural areas (64). $\mathrm{Zn}$ supplementation improves glycemic control and reduces hemoglobin Alc (HbAlc) levels in patients with T2DM $(63,65)$. Besides, $\mathrm{Zn}$ improves glucose metabolism and contributes to glucose uptake into the relevant tissues (66). By inhibiting the activation of cytokines, $\mathrm{Zn}$ deficiency contributes to apoptosis and insulin resistance of $\beta$-pancreatic cells (57). The highest amount of $\mathrm{Zn}$ within the human body is stored in the pancreatic $\beta$-cells, so $\mathrm{Zn}$ ameliorates the consequences of immune-mediated free radicals in pancreatic islet cells (67). In addition, $\mathrm{Zn}$ stimulates phosphorylation of insulin receptor substrates and improves insulin sensitivity (68). Insulin resistance of adipocytes increases the release of fatty acids into the circulation and consequently improves fatty acid flux to the liver leading to hypertriglyceridemia (63). Similarly, Zn affects lipid metabolism directly. $\mathrm{Zn}$ maintains adipose tissue functioning via the activity of $\mathrm{Zn}$ finger proteins involved in the regulation of lipid metabolism (69). $\mathrm{Zn}-\alpha 2$-glycoprotein inactivates hormone-sensitive lipase and accordingly reduces lipogenesis and increases lipolysis in adipose tissues (66). $\mathrm{Zn}$ modulates postprandial lipemia, and Zn deficiency markedly reduces the absorption rate of TGs, brings compositional alterations of chylomicrons, and reduces their production rates and uptake by the liver (70). Thus, $\mathrm{Zn}$ deficiency is often linked to obesity, due to chronic inflammation and oxidative stress. Zn levels in obese subjects are lower than in controls (71-73), and supplementation of $\mathrm{Zn}$ reduces plasma insulin resistance, leptin, and inflammatory biomarkers in obese individuals $(74,75)$.

\section{ZINC HOMEOSTASIS AND CVDs-THE EXISTING CONTROVERSIES}

The link between HT and $\mathrm{Zn}$ status is not decisive, and contradictory findings are reported over the years. Some studies demonstrate an inverse association $(76,77)$, while others found 
a direct positive link between serum $\mathrm{Zn}$ levels and blood pressure $(57,78)$. There are also data signifying no association between the two variables (74-81). Similarly, discrepancies in findings are reported for the risk of developing ARS in relation to serum $\mathrm{Zn}$ levels, and certain data reveal a direct link $(6,82)$, while others show no association between the serum $\mathrm{Zn}$ concentrations and ARS (83). The first randomized controlled trial (RCT) in humans shows adverse effects of $\mathrm{Zn}$ supplementation on HDL-C in healthy subjects (20). However, opposite findings exist, and a positive relation between serum $\mathrm{Zn}$ and HDL-C and LDL-C concentrations is observed (79). Lower consumption of dietary $\mathrm{Zn}$ is related to low HDL-C levels (31).

In addition, $\mathrm{Zn}$ supplementation has a beneficial effect on plasma lipid parameters, and it noticeably reduces TC, LDL-C, and TG levels in healthy individuals (10, 33). The benefits of $\mathrm{Zn}$ supplementation are more evident in nonhealthy population groups. The meta-analysis data show that $\mathrm{Zn}$ supplementation leads to a significant reduction in LDL-C, TC, and TG levels in non-healthy patients, while in healthy people a noteworthy decline in TC levels is seen (33). HDL-C levels increase under $\mathrm{Zn}$ supplementation (20, 33, 77). Large longitudinal prospective cohort studies provide inconsistent findings on the association between supplementary $\mathrm{Zn}$ intake and risk of T2DM, showing both a direct, beneficial (34, 49, 83, 84), an inverse (85), and no relation (86, 87).

Likewise, there are no definitive conclusions on the relationship between $\mathrm{Zn}$ status and T2DM: no association (88) and an inverse link are reported (89) but, lower serum $\mathrm{Zn}$ levels are generally associated with an increased risk of T2DM $(43,90)$.

Different health status of participants, dissimilarities in the design, assessed outcomes across studies and influence of confounding factors and their appropriate adjustments, (i.e., medication, duration of the disease, dietary habits, and physical activity), differences in $\mathrm{Zn}$ assessment methods, lack of distinction in dietary $\mathrm{Zn}$ sources, variations in dietary data collection, and the inconsistency in utilized statistical models may all be potential reasons for observed discrepancies in findings among studies.

\section{RESEARCH GAPS AND RECOMMENDATIONS FOR FURTHER RESEARCH STUDIES}

The precise role of $\mathrm{Zn}$ deficiency mechanisms in the pathogenesis of CVDs is still not known. The biological properties of $\mathrm{Zn}$, playing a role in the physiology and pathology of CVDs, should be examined further. Additional community-based observational cohort studies may be useful for obtaining more precise and evidence-based conclusions on the relation between $\mathrm{Zn}$ and CVDs. It is essential to clarify the instances when inadequate dietary $\mathrm{Zn}$ intake and low $\mathrm{Zn}$ status are a result rather than a cause of CVDs. Particular attention should be paid to exclude the negative effects of medications of CVDs, i.e., diuretic furosemide, angiotensin receptor blockers, and angiotensinconverting enzyme inhibitors, on $\mathrm{Zn}$ status. Larger, welldesigned randomized clinical trials are necessary to thoroughly examine the effect of $\mathrm{Zn}$ intake on $\mathrm{CV}$ health. Potential interactions with other dietary factors and micronutrients that could modulate $\mathrm{Zn}$ intake should be considered. Benefits, clinical applications, risks, and contraindications of dietary and supplemental $\mathrm{Zn}$ intake on main $\mathrm{CV}$ events should be examined further. The impact of the baseline $\mathrm{Zn}$ status on the efficacy of $\mathrm{Zn}$ interventions on CVD risk factors is of great importance and should be appropriately assessed and reported. Risk factors related to CVDs should be examined as primary outcomes of these interventions, and they should aim to examine the development and progression of these conditions. Further research studies should investigate the interaction between $\mathrm{Zn}$ intake and $\mathrm{Zn}$ status data with present preventative schemes and currently employed treatment methods that could help in the prevention and management of many ensuing CVDs.

As $\mathrm{Zn}$ status is affected by various factors, a careful selection of confounders should be made. $\mathrm{Zn}$ deficiency may not only be caused by an inappropriate dietary intake and/or bioavailability but also by factors such as age, physical activity, and alcohol or drug addictions. Further research studies should explore molecular mechanisms that support the sensing and distribution of $\mathrm{Zn}$ in various tissues. The interaction between $\mathrm{Zn}$ and inflammation deserves further research studies. The limitations of biomarkers of $\mathrm{Zn}$ status should be taken into consideration. Circulating plasma/serum $\mathrm{Zn}$ concentrations are affected by inflammation, time of the last meal, infections, and some other factors. All these elements have to be suitably deliberated. Newly proposed biomarkers of $\mathrm{Zn}$ status should be taken into consideration and investigated to CVD-related factors.

The mechanisms of action of $\mathrm{Zn}$ transporter proteins require additional research studies. Detailed and careful analysis of the activities of these transporters is required to improve our knowledge on the pathogenesis of CVDs. The transfer of information from $\mathrm{Zn}$ intake/status to cellular functions needs further extrapolation. New studies are needed to provide a more thorough understanding of MT and ZnT roles and the effects of their common genetic variations. Additional studies are required to explain the interactions between specific genetic profiles and zinc status. Further research studies should clarify gene-nutrient interactions and their relationship with $\mathrm{Zn}$ status and CVDs. It would be beneficial to develop suitable methods for measuring endothelial $\mathrm{Zn}$ as a biomarker of vascular $\mathrm{Zn}$ deficiency. The interplay between $\mathrm{Zn}$ and $\mathrm{NO}$ levels should be further investigated. The expression and functions/dysfunctions of $\mathrm{Zn}$ transporters in vascular tissues and genetic risk factors associated with $\mathrm{Zn}$ transporters should be additionally tested. $\mathrm{Zn}$ homeostasis is altered early in CVDs, so an intervention with Zn-related therapy could provide significant benefits. Preventative CVD actions should include programmed $\mathrm{Zn}$ nutrition approaches. The possibility of therapeutic manipulations of CVDs by Zn-based treatments exists; however, further low-dose short- and/or long-duration 
well-designed studies, across a variety of populations, are needed. The role of $\mathrm{Zn}$ supplementation in the process of recovery from CVDs should be more intensively investigated to find safe and desirable levels of $\mathrm{Zn}$ supplementation and, additionally, to determine the dose and duration that would be most beneficial primarily for the prevention of and, if need be, for the treatment of various ensuing CVD-related pathologies. Appropriate dietary recommendations, food fortification, and agronomic biofortification strategies should all be investigated and employed so that majority of people, both in developing and developed countries, can attain sufficient levels of dietary $\mathrm{Zn}$ in daily diets and potentially diminish the risk of developing CVDs.

\section{REFERENCES}

1. Maxfield L, Crane JS. Available online at: https://www.ncbi.nlm.nih.gov/ books/NBK493231/ (accessed March 20, 2021).

2. Chasapis CT, Loutsidou AC, Spiliopoulou CA, Stefanidou ME. Zinc and human health: an update. Arch. Toxicol. (2012) 86:521-34. doi: 10.1007/s00204-011-0775-1

3. Pae M, Meydani SN, Wu D. The role of nutrition in enhancing immunity in aging. Aging Dis. (2012) 3:91-129.

4. WHO. Available Online at: https:/www.who.int/news-room/fact-sheets/ detail/cardiovascular-diseases-(cvds) (accessed February 18, 2021).

5. Huang L, Teng T, Bian B, Yao W, Yu X, Wang Z, et al. Zinc levels in left ventricular hypertrophy. Biol Trace Elem Res. (2017) 176:48-55. doi: 10.1007/s12011-016-0808-y

6. Choi S, Liu X, Pan Z. Zinc deficiency and cellular oxidative stress: prognostic implications in cardiovascular diseases. Acta Pharmacol Sin. (2018) 39:112032. doi: 10.1038/aps.2018.25

7. Jurowski K, Szewczyk B, Nowak G, Piekoszewski W. Biological consequences of zinc deficiency in the pathomechanisms of selected diseases. J Biol Inorg Chem. (2014) 9:1069-79. doi: 10.1007/s00775-014-1139-0

8. Beattie JH, Gordon M-J, Duthie SJ, McNeil CJ, Horgan GW, Nixon GF, et al. Suboptimal dietary zinc intake promotes vascular inflammation and atherogenesis in a mouse model of atherosclerosis. Molec Nutr. Food Res. (2012) 56:1097-105. doi: 10.1002/mnfr.201100776

9. Beattie JH, Gordon MJ, Rucklidge GJ, Reid MD, Duncan GJ, Horgan GW, et al. Aorta protein networks in marginal and acute zinc deficiency. Proteomics. (2008) 8:2126-35. doi: 10.1002/pmic.200700784

10. Foster M, Petocz P, Samman S. Effects of zinc on plasma lipoprotein cholesterol concentrations in humans: a meta-analysis of randomised controlled trials. Atherosclerosis. (2010) 210:344-52. doi: 10.1016/j.atherosclerosis.2009.11.038

11. Shokrzadeh M, Ghaemian A, Salehifar E, Aliakbari S, Saravi SSS, Ebrahimi P. Serum zinc and copper levels in ischemic cardiomyopathy. Biol Trace Elem Res. (2009) 127:116-23. doi: 10.1007/s12011-008-8237-1

12. Little PJ, Bhattacharya R, Moreyra AE, Korichneva IL. Zinc and cardiovascular disease. Nutrition. (2010) 26:1050-7. doi: 10.1016/j.nut.2010.03.007

13. Munshi A, Babu S, Kaul S, Shafi G, Rajeshwar K, Alladi S, et al. Depletion of serum zinc in ischemic stroke patients. Method Finding Exp Clin Pharm. (2010) 32:433. doi: 10.1358/mf.2010.32.6.1487084

14. Masley SC, Roetzheim R, Masley LV, McNamara T, Schocken DD. Emerging risk factors as markers for carotid intima media thickness scores. J Am Coll Nutr. (2015) 34:100-7. doi: 10.1080/07315724.2014. 916238

15. Lopez V, Keen CL, Lanoue L. Prenatal zinc deficiency: influence on heart morphology and distribution of key heart proteins in a rat model. Biol Trace Elem Res. (2008) 122:238-55. doi: 10.1007/s12011-0078079-2

16. Tomat AL, Costa MdlÁ, Arranz CT. Zinc restriction during different periods of life: influence in renal and cardiovascular diseases. Nutrition. (2011) 27:392-8. doi: 10.1016/j.nut.2010.09.010

\section{AUTHOR CONTRIBUTIONS}

MK conceptualized and wrote the manuscript and prepared the manuscript for submission. MG revised the final version of the manuscript. Both authors contributed to the article and approved the submitted version.

\section{FUNDING}

This work was supported by the Ministry of Education, Science and Technological Development of the Republic of Serbia, Contract 451-03-9/2021-14/200015.

17. Hashemian M, Poustchi H, Mohammadi-Nasrabadi F, Hekmatdoost A. Systematic review of zinc biochemical indicators and risk of coronary heart disease. ARYA Arther. (2015) 11:357-65.

18. Chu A, Foster M, Samman S. Zinc status and risk of cardiovascular diseases and type 2 diabetes mellitus-A systematic review of prospective cohort studies. Nutrients. (2016) 8:707. doi: 10.3390/nu8110707

19. Bao B, Prasad AS, Beck FW, Fitzgerald JT, Snell D, Bao GW, et al. Zinc decreases C-reactive protein, lipid peroxidation, and inflammatory cytokines in elderly subjects: a potential implication of zinc as an atheroprotective agent. Am J Clin Nutr. (2010) 91:1634-41. doi: 10.3945/ajcn.2009.28836

20. Foster M, Samman S. Zinc and regulation of inflammatory cytokines: implications for cardiometabolic disease. Nutrients. (2012) 4:676-94. doi: 10.3390/nu4070676

21. Fagerberg L, Hallström BM, Oksvold P, Kampf C, Djureinovic D, Odeberg $\mathrm{J}$, et al. Analysis of the human tissue-specific expression by genome-wide integration of transcriptomics and antibody-based proteomics. Mol Cell proteomics. (2014) 13:397-406. doi: 10.1074/mcp.M113.035600

22. Zhao L, Oliver E, Maratou K, Atanur SS, Dubois OD, Cotroneo E, et al. The zinc transporter ZIP12 regulates the pulmonary vascular response to chronic hypoxia. Nature. (2015) 524:356-60. doi: 10.1038/nature14620

23. Reiterer G, MacDonald R, Browning JD, Morrow J, Matveev SV, Daugherty $A$, et al. Zinc deficiency increases plasma lipids and atherosclerotic markers in LDL-receptor-deficient mice. J Nutr. (2005) 135:2114-8. doi: $10.1093 /$ jn/135.9.2114

24. Alcantara EH, Shin MY, Feldmann J, Nixon GF, Beattie JH, Kwun IS. Longterm zinc deprivation accelerates rat vascular smooth muscle cell proliferation involving the down-regulation of JNK1/2 expression in MAPK signaling. Atherosclerosis. (2013) 228:46-52. doi: 10.1016/j.atherosclerosis.2013.01.030

25. Cohen N, Golik A. Zinc balance and medications commonly used in the management of heart failure. Heart Fail Rev. (2006) 11:19-24. doi: 10.1007/s10741-006-9189-1

26. Yu X, Huang L, Zhao J, Wang Z, Yao W, Wu X, et al. The relationship between serum zinc level and heart failure: a meta-analysis. Bio Med Res Int. (2018) 2018:2739014. doi: 10.1155/2018/2739014

27. Mohammadifard N, Humphries KH, Gotay C, Mena-Sanchez G, SalasSalvado J, Esmaillzadeh A, et al. Trace minerals intake: risks and benefits for cardiovascular health. Crit Rev Food Sci Nutr. (2019) 59:1334-46. doi: 10.1080/10408398.2017.1406332

28. Alexanian I, Parissis J, Farmakis D, Athanaselis S, Pappas L, Gavrielatos G, et al. Clinical and echocardiographic correlates of serum copper and zinc in acute and chronic heart failure. Clin Res Cardiol. (2014) 103:938-49. doi: 10.1007/s00392-014-0735-x

29. Giannoglou GD, Konstantinou DM, Kovatsi L, Chatzizisis YS, Mikhailidis DP. Association of reduced zinc status with angiographically severe coronary atherosclerosis: a pilot study. Angiology. (2010) 61:449-55. doi: 10.1177/0003319710366702

30. Pilz S, Dobnig H, Winklhofer-Roob BM, Renner W, Seelhorst U, Wellnitz B, et al. Low serum zinc concentrations predict mortality in patients referred to coronary angiography. Br J Nutr. (2009) 101:1534-40. doi: $10.1017 /$ S0007114508084079 
31. Liu B, Cai Z-Q, Zhou Y-M. Deficient zinc levels and myocardial infarction. Biol Trace Elem Res. (2015) 165:41-50. doi: 10.1007/s12011-015-0244-4

32. Karagulova G, Yue Y, Moreyra A, Boutjdir M, Korichneva I. Protective role of intracellular zinc in myocardial ischemia/reperfusion is associated with preservation of protein kinase C isoforms. J Pharmacol Exp Ther. (2007) 321:517-25. doi: $10.1124 /$ jpet.107.119644

33. Ranasinghe $\mathrm{P}$, Wathurapatha W, Ishara M, Jayawardana R, Galappatthy P, Katulanda P, et al. Effects of zinc supplementation on serum lipids: a systematic review and meta-analysis. Nutr Metab. (2015) 12:1-16. doi: 10.1186/s12986-015-0023-4

34. Sun Q, Van Dam RM, Willett WC, Hu FB. Prospective study of zinc intake and risk of type 2 diabetes in women. Diabetes Care. (2009) 32:629-34. doi: $10.2337 / \mathrm{dc} 08-1913$

35. Vashum KP, McEvoy M, Shi Z, Milton AH, Islam MR, Sibbritt D, et al. Is dietary zinc protective for type 2 diabetes? Results from the Australian longitudinal study on women's health. BMC Endocr Disord. (2013) 13:40. doi: 10.1186/1472-6823-13-40

36. Bates CJ, Hamer M, Mishra GD. Redox-modulatory vitamins and minerals that prospectively predict mortality in older British people: the National Diet and Nutrition Survey of people aged 65 years and over. Br J Nutr. (2011) 105:123-32. doi: 10.1017/S0007114510003053

37. Zalewski PD, Beltrame JF, Wawer AA, Abdo AI, Murgia C. Roles for endothelial zinc homeostasis in vascular physiology and coronary artery disease. Crit Rev Food Sci Nutr. (2019) 59:3511-25. doi: 10.1080/10408398.2018.1495614

38. Pompano LM, Boy E. Effects of dose and duration of zinc interventions on risk factors for type 2 diabetes and cardiovascular disease: a systematic review and meta-analysis. Adv Nutr. (2020) 12:141-60. doi: 10.1093/advances/nmab052

39. Giacconi R, Muti E, Malavolta M, Cardelli M, Pierpaoli S, Cipriano C, et al. A novel Zip2 Gln/Arg/Leu codon 2 polymorphism is associated with carotid artery disease in aging. Rejuvenation Res. (2008) 11:297-300. doi: $10.1089 /$ rej.2008.0671

40. Etzion Y, Ganiel A, Beharier O, Shalev A, Novack V, Volvich L, et al. Correlation between atrial ZnT-1 expression and atrial fibrillation in humans: a pilot study. J Cardiovasc Electrophysiol. (2008) 19:157-64. doi: $10.1111 / j .1540-8167.2007 .01008 . x$

41. Mor M, Beharier O, Levy S, Kahn J, Dror S, Blumenthal D, et al. ZnT1 enhances the activity and surface expression of T-type calcium channels through activation of Ras-ERK signaling. Am J Physiol Cell Physiol. (2012) 303:C192-203. doi: 10.1152/ajpcell.00427.2011

42. Shimokawa H. 2014 Williams Harvey Lecture: importance of coronary vasomotion abnormalities-from bench to bedside. Eur Heart J. (2014) 35:3180-93. doi: 10.1093/eurheartj/ehu427

43. Mocchegiani E, Malavolta M. Zinc-gene interaction related to inflammatory/immune response in ageing. Genes Nutr. (2008) 3:61-75. doi: 10.1007/s12263-008-0085-2

44. Virgili F, Ambra R, McCormack J, Simpson EEA, Ciarapica D, Barnaba $\mathrm{L}$, et al. Genetic polymorphisms and zinc status: implications for supplementation in metabolic diseases. Curr Pharm Des. (2018) 24:4131-43. doi: $10.2174 / 1381612824666181016155903$

45. Cheng L, Zhang D, Zhou L, Zhao J, Chen B. Association between SLC30A8 rs13266634 polymorphism and type 2 diabetes risk: a meta-analysis. Med Sci Monit. (2015) 21:2178-89. doi: 10.12659/MSM.894052

46. DeMenna J, Puppala S, Chittoor G, Schneider J, Kim JY, Shaibi GQ, et al. Association of common genetic variants with diabetes and metabolic syndrome related traits in the Arizona insulin resistance registry: a focus on Mexican American families in the Southwest. Hum Hered. (2014) 7:47-58. doi: $10.1159 / 000363411$

47. Costarelli L, Muti E, Malavolta M, Cipriano C, Giacconi R, Tesei S, et al. Distinctive modulation of inflammatory and metabolic parameters in relation to zinc nutritional status in adult overweight/obese subjects. J Nutr Biochem. (2010) 21:432-7. doi: 10.1016/j.jnutbio.2009. 02.001

48. Hosseini-Esfahani F, Mirmiran P, Koochakpoor G, Daneshpour MS, Guity K, Azizi F. Some dietary factors can modulate the effect of the zinc transporters 8 polymorphism on the risk of metabolic syndrome. Sci Rep. (2017) 7:1649. doi: 10.1038/s41598-017-01762-9
49. Adams JN, Martelle SE, Raffield LM, Freedman BI, Langefeld CD, Hsu F-C, et al. Analysis of advanced glycation end products in the DHS Mind Study. $J$ Diabetes Complicat. (2016) 30:262-8. doi: 10.1016/j.jdiacomp.2015.11.025

50. Yang L, Li H, Yu T, Zhao H, Cherian MG, Cai L, et al. Polymorphisms in metallothionein-1 and-2 genes associated with the risk of type 2 diabetes mellitus and its complications. Am J Physiol Endocrinol Metab. (2008) 294:E987-92. doi: 10.1152/ajpendo.90234.2008

51. Kozarova R, Postadzhiyan A, Finkov B, Apostolova M. Association of copy number variations and single nucleotide polymorphisms in metallothionein genes with pathogenesis of diabetes and coronary artery disease. Atheroscl Suppl. (2011) 12:107. doi: 10.1016/S1567-5688(11)70504-9

52. Jing L, Yang M, Li Y, Yu Y, Liang B, Cao L, et al. Metallothionein prevents doxorubicin cardiac toxicity by indirectly regulating the uncoupling proteins 2. Food Chem Toxicol. (2017) 110:204-13. doi: 10.1016/j.fct.2017.10.035

53. Xiang J, Li XY, Xu M, Hong J, Huang Y, Tan J-R, et al. Zinc transporter-8 gene (SLC30A8) is associated with type 2 diabetes in Chinese. J Clin Endocrinol Metab. (2008) 93:410712. doi: 10.1210/jc.2008-0161

54. Gomes KFB, Semzezem C, Batista R, Fukui RT, Santos AS, Correia $\mathrm{MR}$, et al. Importance of zinc transporter 8 autoantibody in the diagnosis of type 1 diabetes in Latin Americans. Sci Rep. (2017) 7:2017. doi: 10.1038/s41598-017-00307-4

55. Yary T, Virtanen JK, Ruusunen A, Tuomainen T-P, Voutilainen S. Serum zinc and risk of type 2 diabetes incidence in men: the Kuopio ischaemic heart disease risk factor study. J Trace Elem Med Biol. (2016) 33:120-4. doi: 10.1016/j.jtemb.2015.11.001

56. Ahn B-I, Kim MJ, Koo HS, Seo N, Joo N-S, Kim Y-S. Serum zinc concentration is inversely associated with insulin resistance but not related with metabolic syndrome in nondiabetic Korean adults. Biol Trace Elem Res. (2014) 160:16975. doi: 10.1007/s12011-014-0045-1

57. Ruz M, Carrasco F, Rojas P, Basfi-fer K, Hernández MC, Pérez A. Nutritional effects of zinc on metabolic syndrome and type 2 diabetes: mechanisms and main findings in human studies. Biol Trace Elem Res. (2019) 188:177-88. doi: 10.1007/s12011-018-1611-8

58. Prasad AS, Bao B. Molecular mechanisms of zinc as a pro-antioxidant mediator: clinical therapeutic implications. Antioxidants. (2019) 8:164. doi: 10.3390/antiox 8060164

59. Chabosseau P, Rutter GA. Zinc and diabetes. Arch Biochem Biophys. (2016) 611:79-85. doi: 10.1016/j.abb.2016.05.022

60. Shan Z, Bao W, Zhang Y, Rong Y, Wang X, Jin Y, et al. Interactions between zinc transporter- 8 gene and plasma zinc concentrations for impaired glucose regulation and type 2 diabetes. Diabetes. (2014) 63:1796-803. doi: $10.2337 / \mathrm{db} 13-0606$

61. Barman S, Srinivasan K. Diabetes and zinc dyshomeostasis: can zinc supplementation mitigate diabetic complications? Crit Rev Food Sci Nutr. (2020). doi: 10.1080/10408398.2020.1833178. [Epub ahead of print].

62. Praveeena S, Pasula S, Sameera K. Trace elements in diabetes mellitus. J Clin Diagn Res. (2013) 7:1863-5. doi: 10.7860/JCDR/2013/5464.3335

63. Capdor J, Foster M, Petocz P, Samman S. Zinc and glycemic control: a metaanalysis of randomised placebo controlled supplementation trials in humans. J Trace Elem Med Biol. (2013) 27:137-42. doi: 10.1016/j.jtemb.2012.08.001

64. Fernández-Cao JC, Warthon-Medina M, H Moran V, Arija V, Doepking C, Serra-Majem L, et al. Zinc intake and status and risk of type 2 diabetes mellitus: a systematic review and meta-analysis. Nutrients. (2019) 11:1027. doi: 10.3390/nu11051027

65. de Carvalho GB, Brandão-Lima PN, Maia CS, Barbosa KB, Pires LV. Zinc's role in the glycemic control of patients with type 2 diabetes: a systematic review. Biometals. (2017) 30:15-62. doi: 10.1007/s10534-017-9996-y

66. Olechnowicz J, Tinkov A, Skalny A, Suliburska J. Zinc status is associated with inflammation, oxidative stress, lipid, and glucose metabolism. J Physiol Sci. (2018) 681:19-31. doi: 10.1007/s12576-017-0571-7

67. Maret W. Zinc in pancreatic islet biology, insulin sensitivity, and diabetes. Prev Nutr Food Sci. (2017) 22:1-8. doi: 10.3746/pnf.2017.22.1.1

68. Mocchegiani E, Giacconi R, Malavolta M. Zinc signalling and subcellular distribution: emerging targets in type 2 diabetes. Trends Mol Med. (2008) 14:419-28. doi: 10.1016/j.molmed.2008.08.002

69. Fukunaka A, Fujitani Y. Role of zinc homeostasis in the pathogenesis of diabetes and obesity. Int J Mol Sci. (2018) 19:476. doi: 10.3390/ijms19020476 
70. Desmarchelier C, Borel P, Lairon D, Maraninchi M, Valero R. Effect of nutrient and micronutrient intake on chylomicron production and postprandial lipemia. Nutrients. (2019) 11:6. doi: 10.3390/nu11061299

71. Virdis A, Neves MF, Duranti E, Bernini G, Taddei S. Microvascular endothelial dysfunction in obesity and hypertension. Curr Pharm Des. (2013) 19:2382-9. doi: 10.2174/1381612811319130006

72. Knez M, Nikolic M, Zekovic M, Stangoulis JCR, Gurinovic M, Glibetic M. The influence of food consumption and socio-economic factors on the relationship between zinc and iron intake and status in a healthy population. Public Health Nutr. (2017) 20:2486-98. doi: 10.1017/S1368980017001240

73. Knez M, Pantovic A, Zekovic M, Pavlovic Z, Glibetic M, Zec M. Is there a link between zinc intake and status with plasma fatty acid profile and desaturase activities in dyslipidemic subjects? Nutrients. (2020) 12:93. doi: 10.3390/nu12010093

74. Kelishadi R, Hashemipour M, Adeli K, Tavakoli N, Movahedian-Attar A, Shapouri J, et al. Effect of zinc supplementation on markers of insulin resistance, oxidative stress, and inflammation among prepubescent children with metabolic syndrome. Metab Syndr Relat Disord. (2010) 8:505-10. doi: $10.1089 /$ met.2010.0020

75. Gunasekara P, Hettiarachchi M, Liyanage C, Lekamwasam S. Effects of zinc and multimineral vitamin supplementation on glycemic and lipid control in adult diabetes. Diabetes Metab. Syndr. Obes. (2011) 4:53-60. doi: 10.2147/DMSO.S16691

76. Afridi HI, Kazi TG, Kazi N, Talpur FN, Arain SS, Brahman KD, et al. Distribution of copper, iron, and zinc in biological samples of Pakistani hypertensive patients and referent subjects of different age groups. Clin Labor. (2013) 59:9-10:959-67. doi: 10.7754/Clin.Lab.2012.120704

77. Kim J. Dietary zinc intake is inversely associated with systolic blood pressure in young obese women. Nutr Res Pract. (2013) 7:380. doi: $10.4162 /$ nrp.2013.7.5.380

78. Ghayour-Mobarhan M, Shapouri-Moghaddam A, Azimi-Nezhad M, Esmaeili H, Parizadeh S, Safarian M, et al. The relationship between established coronary risk factors and serum copper and zinc concentrations in a large Persian cohort. J Trace Elem Med Biol. (2009) 23:167-75. doi: 10.1016/j.jtemb.2009.03.006

79. Tsuboi A, Terazawa M, Kazumi T, Fukuo K. Serum copper, zinc and risk factors for cardiovascular disease in community-living Japanese elderly women. Asia Pac J Clin Nutr. (2014) 23:239-45. doi: 10.6133/apjen.2014.23.2.04

80. Lutfi MF, Elhakeem RF, Khogaly RSKS, Abdrabo AA, Ali AB, Gasim GI, et al. Zinc and copper levels are not correlated with angiographically-defined coronary artery disease in sudanese patients. Front Physiol. (2015) 6:191. doi: 10.3389/fphys.2015.00191

81. Kunutsor SK, Laukkanen JA. Serum zinc concentrations and incident hypertension: new findings from a population-based cohort study. $J$ Hypertens. (2016) 34:1055-61. doi: 10.1097/HJH.0000000000000923

82. Islamoglu Y, Evliyaoglu O, Tekbas E, Cil H, Elbey MA, Atilgan Z, et al. The relationship between serum levels of $\mathrm{Zn}$ and $\mathrm{Cu}$ and severity of coronary atherosclerosis. Biol Trace Elem Res. (2011) 144:436-44. doi: 10.1007/s12011-011-9123-9

83. De Paula RC, Aneni EC, Costa APR, Figueiredo VN, Moura FA, Freitas WM, et al. Low zinc levels is associated with increased inflammatory activity but not with atherosclerosis, arteriosclerosis or endothelial dysfunction among the very elderly. BBA Clin. (2014) 2:1-6. doi: 10.1016/j.bbacli.2014.07.002

84. Drake I, Hindy G, Ericson U, Orho-Melander M. A prospective study of dietary and supplemental zinc intake and risk of type 2 diabetes depending on genetic variation in SLC30A8. Genes Nutr. (2017) 12:1-11. doi: 10.1186/s12263-017-0586-y

85. de Oliveira Otto MC, Alonso A, Lee DH, Delclos GL, Bertoni AG, et al. Dietary intakes of zinc and heme iron from red meat, but not from other sources, are associated with greater risk of metabolic syndrome and cardiovascular disease. J Nutr. (2012) 142:526-33. doi: 10.3945/jn.111.149781

86. Park JS, Xun P, Li J, Morris SJ, Jacobs DR, Liu K, et al. Longitudinal association between toenail zinc levels and the incidence of diabetes among American young adults: the CARDIA. Trace Elem Study Sci Rep. (2016) 6:1-6. doi: 10.1038/srep23155

87. Simić A, Hansen AF, Åsvold BO, Romundstad PR, Midthjell K, Syversen $\mathrm{T}$, et al. Trace element status in patients with type 2 diabetes in Norway: the HUNT3 Survey. J Trace Elem Med Biol. (2017) 41:91-8. doi: 10.1016/j.jtemb.2017.03.001

88. Skalnaya MG, Skalny AV, Yurasov VV, Demidov VA, Grabeklis AR, Radysh IV, et al. Serum trace elements and electrolytes are associated with fasting plasma glucose and $\mathrm{HbA} 1 \mathrm{c}$ in postmenopausal women with type 2 diabetes mellitus. Biol Trace Elem Res. (2017) 177:25-32. doi: 10.1007/s12011-016-0 868-z

89. Hansen AF, Simić A, Åsvold BO, Romundstad PR, Midthjell K, Syversen T, et al. Trace elements in early phase type 2 diabetes mellitus-A populationbased study. The HUNT study in Norway. J Trace Elem Med Biol. (2017) 40:46-53. doi: 10.1016/j.jtemb.2016.12.008

90. Ranasinghe P, Wathurapatha WS, Galappatthy P, Katulanda P, Jayawardena $\mathrm{R}$, Constantine GR. Zinc supplementation in prediabetes: a randomized double-blind placebo-controlled clinical trial. J Diabetes. (2018) 10:386-97. doi: $10.1111 / 1753-0407.12621$

Conflict of Interest: The authors declare that the research was conducted in the absence of any commercial or financial relationships that could be construed as a potential conflict of interest.

The handling editor disclosed a past co-authorship with the authors MG and MK.

Publisher's Note: All claims expressed in this article are solely those of the authors and do not necessarily represent those of their affiliated organizations, or those of the publisher, the editors and the reviewers. Any product that may be evaluated in this article, or claim that may be made by its manufacturer, is not guaranteed or endorsed by the publisher.

Copyright (c) $2021 \mathrm{Knez}$ and Glibetic. This is an open-access article distributed under the terms of the Creative Commons Attribution License (CC BY). The use, distribution or reproduction in other forums is permitted, provided the original author(s) and the copyright owner(s) are credited and that the original publication in this journal is cited, in accordance with accepted academic practice. No use, distribution or reproduction is permitted which does not comply with these terms. 